SOSIOLOGI INSPIROITUI SOSIAALIPOLITIIKASTA

Jorma Sipilä: sosiaalipolitiikan, erityisesti sosiaalityön emeritusprofessori, Tampereen yliopisto

Hannu Uusitalo: Tutkimus ja päätöksenteko hyvinvointivaltiossa. Havaintoja viideltä vuosikymmeneltä. Into, Helsinki. 2020, 324 s.

Kun puhutaan tutkimuksen ja päätöksenteon suhteesta suomalaisessa hyvinvointivaltiossa, kannattaa kuunnella Hannu Uusitaloa. Hän aloitti työuransa yliopistomaailmassa, siirtyi sitten sosiaali- ja terveyshallitukseen, josta pian tuli Stakes, ja lopulta Eläketurvakeskukseen. Työympäristöjen vaihdot ovat avanneet uusia näkökulmia, ja runsas dokumenttiaineisto vahvistaa kertomusta hyvinvointivaltion tekemisessä käytetyn tiedon ja tutkimuksen muutoksesta. Kirjan painopiste on tiedepolitiikassa, ei muistelmissa, eikä sen sankarina ole vaatimaton kirjoittaja yksin, vaan hyvinvointivaltion tutkijat ja heidän kanssaan keskustelevat päätöksentekijät.

Yliopistouralleen Uusitalo sai varmaankin parhaan kuviteltavissa olevan alun - hän pääsi vuonna 1971 mukaan Erik Allardtin Vertailevan sosiologian tutkimusryhmään. Erik Allardt oli huomattava teoreetikko ja erinomainen tutkimuksen ohjaaja. Ryhmä teki yhdessä pohjoismaisten kumppaniensa kanssa uraa uurtavaa, vertailevaa hyvinvointitutkimusta. Uusitalosta tuli kansainvälisesti erittäin hyvin verkostoitunut tulonjaon, sen muutoksen ja merkityksen tutkija.
Hannu Uusitalo eteni jo nuorena $\mathrm{Tu}-$ run ja sittemmin Helsingin kauppakorkeakoulun apulaisprofessoriksi, mutta ei lopulta ottanut vastaan sosiologian professuuria Tampereen yliopistossa Miksi ei? Uusitalo selittää päätöstään sillä muutoksella, mikä tapahtui sosiologian ja yhteiskunnan välisessä suhteessa 1980-luvulla. Sosiologia ei enää ollut siinä yhteiskunnallisen keskustelun ja tutkimuksen keskiössä, mihin erityisesti Erik Allardt ja Antti Eskola olivat sen tuoneet. Tieteenala "näytti yhä enemmän hakevan keskustelukumppaninsa pikemminkin sosiologian sisältä kuin yhteiskunnasta." Taloustieteilijöiden asema yhteiskunnallisessa keskustelussa oli voimistunut ja yhteiskunnallisen tiedontuotannon painopiste oli siirtymässä yliopistolaitoksen ulkopuolelle, esimerkiksi Tilastokeskukseen ja tutkimuslaitoksiin.

Sosiologian metodologinen innovatiivisuus suuntautui 1980-luvulla kvalitatiivisiin menetelmiin. Kvalitatiivisella tutkimuksella ei Uusitalon käsityksen mukaan ollut kuitenkaan menestystä yhteiskuntapoliittisen päätöksenteon tukena.Yhteiskuntapoliittiset uudistukset vaativat tutkimukselta suuruus- ja vaikutussuhteita osoittavia numeroita. Uusitalo halusi olla mukana tutkimassa yhteiskunnallisia ongelmia ja etsimässä niille poliittisia ratkaisuja. Hän koki sosiologian vetovoiman hiipuvan, kun taas yhteiskunta- ja sosiaalipoliittiset ongelmat näyttivät entistä kiinnostavimmilta.

Hannu Uusitalo siirtyi vastaperustettuun sosiaali- ja terveyshallitukseen, tietopalveluosaston ylijohtajaksi (1991). Puolitoista vuotta myöhemmin uusi 
instituutio luopui hallintovallasta ja ennakoi siinä kuntien vapautumista valtion tiukasta ohjauksesta (1995). Sosiaali- ja terveyshallituksesta tehtiin Stakes-niminen tutkimus- ja kehittämiskeskus. Kun Stakes oli selviytynyt sektoritutkimuslaitosten supistamishankkeesta, pääjohtaja Vappu Taipale kehitti keskusta voimakkaasti sekä tutkimusinstituutiona että yhteiskuntaa palvelevana tietokeskuksena. Uusitalo oli käynnistämässä laajaa tutkimushanketta laman vaikutuksista sosiaali- ja terveydenhuoltoon sekä väestön toimeentuloon. Hän oli myös panemassa liikkeelle arvokkaita, säännöllisesti toistuvia katsauksia kansanterveydestä, toimeentulosta ja sosiaalipalveluista. $\mathrm{Ne}$ eivät ole palvelleet ainoastaan päätöksentekijöitä, vaan yhteiskunnallista ajattelua ylipäänsä.

Stakes-vuosinaan Uusitalo kertoo oppineensa arvostamaan hallintoa ja virkamiesten pätevyyttä ja näkemään johtamisen merkityksen. Muutaman vuoden kuluttua Uusitalo ei enää uskonut sanoneensa, ettei tutkimusta voi ohjata. "Jos johtaminen tuo tulosta, niin se näkyy parhaassa tapauksessa koko Stakesin toiminnassa, toiseksi parhaassa tapauksessa kymmenien ihmisten toimintamahdollisuuksien ja -tapojen parantumisena... kun taas oma asiantuntijatyö tuottaa tulosta vain oman asiantuntijantyön osalta." Toisaalta hän joutui myös toteamaan, että tieto-ohjauksella oli rajansa: "Ehkä luotettiin liikaa myös siihen, että kunnallinen (ja valtiollinen) demokratia toteuttaa automaattisesti tehokkaita ja hyväksi osoitettuja käytäntöjä.”
Valtion toistuvat pyrkimykset supistaa sektoritutkimusta kismittivät Uusitaloa. Sosiaali- ja terveydenhuollon alalla supistukset merkitsivät selvästi heikentyneitä mahdollisuuksia tehdä tietoon perustavaa politiikkaa. Sellaisen politiikan tekemisen edellytykset eivät synny noin vain kilpailuttamalla hankkeita vapailla markkinoilla. Tietoa on koottava taitavasti ja pitkäjänteisesti, yhteistyösuhteet rakennettava, infra hankittava ja tietojenkäsittelyn teknologioita kehitettävä. Onnistuminen edellyttää vuosia kestävää kansainvälistä oppimisja rakentamisprosessia. Päätöksenteon palveleminen on sektoritutkimuslaitosten leipälaji, kun taas yliopistot ovat parhaimmillaan uusien ideoiden, teorioiden ja tutkimukseen perustuvan kritiikin kehittelyssä.

Uusitalo siirtyi vuonna 2001 suunnittelujohtajaksi Eläketurvakeskukseen. Hyvinvointivaltiossa tuskin on instituutiota, jolle tieto on tärkeämpää kuin tälle työeläketurvan informaatiokeskukselle. Eläkejärjestelmien perustamisessa, niiden talouden ylläpitämisessä ja eläkkeiden tyydyttävän tason säätämisessä täsmällinen tieto on korvaamatonta. Toisaalta oleellinen tieto on monelta osin epävarmaa: tulevien vuosien talouskehitystä, työllisyyttä, palkkatasoa, eläkkeelle siirtymisen halukkuutta ja väestön määrää ei ole mahdollista ennakoida varmasti. Isot muutokset näissä johtavat muutoksiin eläkejärjestelmissä. Epävarmuuksiin on vastattu yhtäältä tietokantojen valtavalla kehittämistyöllä ja toisaalta luomalla automaattisia tasapainottajia, kuten elinaikakerroin ja eläkkeelle siirtymisiän säätäminen seuraamaan eliniän muutoksia. Eläketurvakeskuksessakin Uusitalo oli pitä- 
mässä huolta siitä, että poliittisen vallan korkein haltija eli kansa tietää, missä yhteiskunta menee. Nyt oli vuorossa aloite Tilastokeskuksen Findikaattorin perustamisesta.

Eläkkeisiin liittyy kovia poliittisia paineita. Hyvä esimerkki siitä on jo kohta neljännesvuosisadan jatkunut keskustelu taitetusta työeläkeindeksistä. Kymmenien tuhansien kansalaisten vaatima indeksimuutos johtaisi siihen, että suorittamiinsa maksuihin verrattuna vanhat sukupolvet voittaisivat eläkkeissä nykyistäkin enemmän. Nuoret maksaisivat laskun. Muutos ei Uusitalon mukaan myöskään ratkaisisi eläkeläisten köyhyyttä,joka kohdistuu erityisesti 75 vuotta täyttäneisiin naisiin. Uusitalon arviot eläkejärjestelmien voittajista ja häviäjistä sisältävät kiinnostavaa informaatiota. Lopputulokseen vaikuttavia tekijöitä on enemmän kuin maallikko tulee ajatelleeksi.

Hannu Uusitalon kirja on voimakas puheenvuoro päätöksentekoa tukevien sektoritutkimuslaitosten puolesta. Hän huomauttaa kuitenkin, että muutakin tarvitaan. Sektoritutkimus ei kyseenalaista asioita samalla tavalla kuin riippumattoman akateemisen tutkimuksen on mahdollista ja tärkeää tehdä. Omasta puolestani haluan täydentää, että me tarvitsemme sosiaalitutkimusta myös oman elämämme ja ympäristömme tilan ja muutoksen ymmärtämiseen. Demokratiassa meidän on ensin päätettävä, mitä me politiikalta haluamme - siitä vasta alkaa päätöksentekijöiden tehtävä.

\section{SOSIAALITYÖN POLIITTISUUS KITEYTYY RAKENTEELLISESSA SOSIAALITYÖSSÄ}

Minna Kivipelto: YTT, dosentti, Terveyden ja hyvinvoinnin laitos

Bob Mullaly \& Marilyn Dupré: The New Structural Social Work: Ideology, Theory, and Practice. Neljäs painos. Oxford University Press, Oxford. 2019 $412 \mathrm{~s}$.

Bob Mullaly ja Marilyn Dupré käsittelevät teoksessaan The New Structural Social Work: Ideology, Theory, and Practice rakenteellisen sosiaalityön tausta-ajattelua ja erilaisia ideologisia suuntauksia sekä rakenteellisen sosiaalityön teoriaa, käytännön menetelmiä ja ratkaisuja. Tekijöiden tavoitteena on osoittaa rakenteellisen sosiaalityön ideologisen taustan ja teoreettisten perusteiden merkitys.

Mullalyn ja Duprén teos on ollut jo pitkään keskeinen kriittisen ja radikaalin sosiaalityön lähde. Kirjan ensimmäinen painos julkaistiin vuonna 1993 (Structural social work: ideology, theory, and practice), toinen painos 1997 ja kolmas painos vuonna 2007 (The new structural social work). Neljäs korjattu painos on vuodelta 2019. Kirjoittajat perustelevat uuden painoksen ottamista muun muassa sillä, että ensimmäinen painos oli koostettu pääosin modernin teoreettisen viitekehyksen mukaisesti. Toisenkin painoksen aikaan postmodernit teoriat tekivät vasta tuloaan. Kirjoittajien mukaan toisen painoksen heikkoutena oli myös se, ettei siinä ollut selkeää suunnitelmaa tai strategiaa heikompien ryhmi- 
en auttamiseksi. Näitä näkökulmia on tarkennettu myöhemmissä painoksissa.

Molemmilla kirjoittajilla on vahvat juuret kriittisen, sortoa ja syrjintää vastustavan sosiaalityön tutkijoina, käytäntöjen kehittäjinä ja opettajina Australiassa Manitoban yliopistossa, jossa Mullaly yhä työskentelee emeritusprofessorina. Marilyn Dupré vaikuttaa puolestaan St Thomasin Yliopistossa Floridassa. Hän on aiemmin opettanut niin ikään Manitoban yliopiston sosiaalityön yksiköissä.

Rakenteellinen sosiaalityö ei ole uusi ajatus, mutta sen käytäntöön saamista on Suomessa pidetty vaikeana, vaikka rakenteellisen sosiaalityön velvoite on meillä peräti lainsäädännössä. Sosiaalihuoltolaissa rakenteellisella sosiaalityöllä tarkoitetaan sosiaalista hyvinvointia ja sosiaalisia ongelmia koskevan tiedon välittymistä ja sosiaalihuollon asiantuntemuksen hyödyntämistä hyvinvoinnin ja terveyden edistämisessä. Näkemys edustaa Mullalyn ja Duprén jäsennyksessä lähinnä konventionaalista lähestymistapaa sosiaalisiin ongelmiin, koska siinä korostuu asiantuntijoiden ääni. Kirjoittajien mukaan tämänkaltainen rakenteellinen sosiaalityö ei kykene vaikuttamaan sosiaalisten ongelmien alkuperäisiin syihin, joita tässä kutsun juurisyiksi. Juurisyyt ovat ajattelun, toiminnan ja yhteiskunnallisten käytäntöjen verkkoja, jotka ylläpitävät esimerkiksi eri ihmisryhmien välistä eriarvoisuutta.

Juurisyihin tulisi Mullalyn ja Duprén mukaan vaikuttaa kriittisen ja radikaalin sosiaalityön keinoin, koska vain siten on mahdollista muuttaa yhteiskunnan epätasa-arvoa, sortoa ja syrjäytymistä aiheuttavia rakenteita. Vaikeaa tässä on se, että juurisyyt eivät ole aina edes niiden ihmisten tiedossa, jotka niistä eniten hyötyvät. Tämä johtuu siitä, että sortoa ja epäoikeudenmukaisuutta uusinnetaan tiedostamattomasti. Epätasaarvoa uusintava ele voi olla jopa hyvää tarkoittava, jota eteläafrikkalainen Rian Malan (1990) kuvaa kirjassaan Petturin sydän: Malanin täti puhutteli miehen mustaa työtoveria puhumalla tälle pidginiä, lukutaidottomien palvelijoiden lapsenomaista englantia. Lähempää löytyviä esimerkkejä juurisyistä voisivat olla sosiaali- ja terveydenhuollossa olevat käytänteet, joiden vuoksi osa palveluja tarvitsevista ei saa tarvitsemaansa palvelua. Esimerkiksi perustoimeentulotuen osalta on havaittu, että asiakkaan ohjaaminen Kelasta kunnan sosiaalityöhön sisältää monia vaiheita ja pullonkauloja, jolloin on riskinä, että asiakas putoaa pois joko tarvitsemistaan palveluista tai etuuksista tai molemmista (Jokela ym. 2019). Koposen ym. (2020) julkaisussa on puolestaan kuvattu, miten koronaepidemian seurauksena palveluita jouduttiin sulkemaan ja osa ihmisistä ei saanut tarvitsemaansa tukea ja apua. Kriittisiin ja radikaaleihin teorioihin pohjautuvassa rakenteellisessa sosiaalityössä edellä mainitun kaltaiset juurisyyt kaivetaan esiin, lisätään tietoisuutta niistä ja tehdään suunnitelma, miten epäasianmukaiset ja sortavat käytännöt poistetaan.

Kirjoittajien mukaan rakenteellisen sosiaalityön tavoitteena on oikeudenmukainen ja tasa-arvoinen yhteiskunta, jolla voidaan kuitenkin tarkoittaa hyvinkin erilaisia asioita riippuen paradigmasta. Konventionaalisen paradigman mukaan riittää, jos tasa-arvo ja oikeudenmukaisuus on määritelty asiantuntijoiden, kuten oikeusoppineiden toimesta. Tällöin 
esimerkiksi vähimmäisturvan saajien rankaiseminen perustoimeentulotuen alentamisella ei ole ongelma vaan osa konventionaalista logiikkaa, jolla vähimmäisturvan varassa eläviä tulee tässä maassa kohdella.

Rakenteellinen sosiaalityö voi siis ammentaa tavoitteensa erilaisista ideologisista suuntauksista. Uuskonservatismi, liberalismi, uusliberalismi, sosiaalidemokraattinen, marxilainen ja feministinen paradigma sisältävät kaikki erilaisen näkemyksen siitä, mitä tasa-arvo ja oikeudenmukaisuus tarkoittavat ja miten ne saavutetaan. Parhaiten niin sanottuihin juurisyihin pureutuva sosiaalityö nojaa Mullalyn ja Duprén mukaan radikaaleihin ja kriittisiin teorioihin, koska vain niiden avulla on mahdollista analysoida yhteiskunnassa ja sen tuottamissa palveluissa olevaa sortoa ja syrjintää.

Kirjoittajien mukaan käsitteenä "rakenteellinen" (structural) on valittu tämän teoksen nimeen sen takia, että käsite kertoo siitä, mistä sosiaaliset ongelmat ovat peräisin: sosiaaliset ongelmat juontavat uusliberaalista, kapitalistisesta yhteiskunnasta ja niitä ei voi palauttaa yksilöön (s. XIV). Sosiaaliset ongelmat syntyvät ja myös poistuvat sosiaalisissa suhteissa. Tästä syystä sosiaalityössä rakenteiden on oltava muutoksen kohteena, ei esimerkiksi yksilön persoonallisten ominaisuuksien. Esimerkiksi Petturin sydämessä kuvatut valkoisen väestönosan mustia vähättelevät asenteet ja ajattelutavat edustivat rakenteellisia tekijöitä, eivät yksilön tietoisia valintoja tai persoonallisia ominaisuuksia. Avainsana onkin tietoisuus, jota jo Paulo Freire (1970/2005) aikoinaan avasi teoksessaan Sorrettujen pedagogiikka. Rakenteellisessa sosiaali- työssä tavoitellaan kaikkien sorrettujen ryhmien aseman parantamista syvällisen ymmärryksen kautta. Väärät dikotomiat ja binäriset vastakkainasettelut eivät kuulu rakenteelliseen sosiaalityöhön, Mullaly ja Dupré kirjoittavat.

Kirjoittajat kritisoivat sosiaalityön epäpolitisoitumista ja sen poliittisen tehtävän kieltämistä. Heidän mukaansa monet sosiaalityöntekijät saattavat esimerkiksi allekirjoittaa sen, että jokainen ihminen on yhtä arvokas, mutta hyväksyvät silti kilpailuun ja yksilön riistoon perustuvan kapitalistisen yhteiskunnan periaatteet. Suomessa soisi käytävän enemmän tämänkaltaista keskustelua, onko näin ja miksi näin on.

Kirjoittajat myös syyttävät jonkin verran sosiaalityötä sen omasta alemmuudentunteesta. Kirjoittajien mukaan tämä johtuu siitä, että sosiaalityöllä ei ole selkeää visiota tai julkilausuttua näkemystä siitä, millaista yhteiskuntaa meidän tulisi tavoitella. Nähdäkseni tämä on Suomessa johtanut siihen, että sosiaalityön ammattilaiset eivät aina pysty yhtä tarkkaan eksplikoimaan tavoitteitaan tai asiantuntemustaan monialaisissa verkostoissa, kuin esimerkiksi terveydenhuollon ammattilaiset.

Kirjoittajat pitävät kuitenkin pohjoismaista hyvinvointivaltiota mallina, joka on tällä hetkellä lähimpänä sellaista yhteiskuntamallia, jossa kriittisen ja radikaalin sosiaalityön edellytykset on parhaiten otettu huomioon.

Monet kansainväliset kriittisen sosiaalityön tutkijat ja asiantuntijat ovat suorasanaisia, eivätkä kohtele sosiaalityötä silkkihansikkain, vaan asettavat ammat- 
tikunnan edustajat suuriin saappaisiin yhteiskunnallisen sorron, syrjinnän ja epätasa-arvon poistamisessa. Tästä nimenomaisesta syystä johtuen vaativahkot sosiaalityön ideologisen perustan tarkastelut voivat monelta jäädä hyllyyn. Houkuttelevaksi kirjan tekee kuitenkin asian ajankohtaisuus: käynnissä on sosiaalihuollon kansallinen kehittämisohjelma, jossa yhtenä teemana on rakenteellisen sosiaalityön kokonaisuuden selvittäminen. Sosiaalihuollon kehittämisohjelmassa kartoitetaan rakenteellisen sosiaalityön teoreettis-metodiset perusteet, johon käsillä oleva teos antaa hyvän pohjan. Kirjasta on hyötyä myös rakenteellisen sosiaalityön toteutustapojen mallinnuksessa. Lopulta teos antaa ajattelun aihetta kaikille, joita sosiaalityön yhteiskunnalliset perusteet kiinnostavat. Kirjaa voi suositella kaikille sosiaalityön tutkijoille ja opiskelijoille, joille sosiaalityön teoreettis-metodisten periaatteiden paikantaminen on tärkeää.

\section{KirjallisuUs}

Freire, Paulo (1970/2005) Sorrettujen pedagogiikka. [Alkuperäisteos: Pedagogia do oprimido] Suom. Joel Kuortti. Toim. Tuukka Tomperi. Tampere:Vastapaino.

Jokela, Merita \& Kivipelto, Minna \& Ylikännö, Minna (2019) Toimeentulotuelta sosiaalityön asiakkaaksi - sosiaalityöhön ohjaaminen Kelan ja kunnan rajapinnassa. Työpaperi 26/2019. Helsinki: Terveyden ja hyvinvoinnin laitos.

Koponen, Erja \& Liukko, Eeva \& Muurinen, Heidi (2020) Koronasta aiheutuva palveluvaje työikäisten sosiaalipalveluissa. Tutkimuksesta tiiviisti 29/2020. Helsinki: Terveyden ja hyvinvoinnin laitos.

Malan, Rian (1990) Petturin sydän. [Alkuperäisteos: My Traitor's Heart] Suom. Ilkka Malinen. Juva:WSOY.

\section{Keskustelua toivosta, AVOIMUUDESTA JA OIKEUTUKSESTA}

Heidi Sinevaara-Niskanen: $F T, y l i-$ opistonlehtori, Lapin yliopisto

- Risto Saarinen: Oppi toivosta. Gaudeamus, Tallinna Raamatutrükikoda, Tallinna. 2020, 192s.

Nostaessani postilaatikostani Risto Saarisen uuden toivoa käsittelevän teoksen, tulin spontaanisti todenneeksi ääneen "onpa kaunis". Totta tosiaan, teoksen koko ulkoasu on akateemiseksi teokseksi harvinaisen luokseen kutsuva. Vihreän, valkean ja kullan sävyttämässä etukannessa on ylöspäin avautuva käsi, johon kukkiva köynnös kietoutuu. Kämmenellä oleva kultainen lehti on kuin palava liekki ja näyttää, että sormet tavoittelevat kohti seuraavaa, ylempänä roikkuvaa köynnöstä. Kannen metaforat - avoin kämmen, liekki ja kurotus kohti tulevaa - niveltyvät hienosti teoksen pohdintoihin toivosta, sen luonteesta ja oikeutuksesta. Toivo on läsnä, mutta toisaalta sen kohteet ovat usein jossakin tulevassa. Toivo voi olla voimavara, kirkkaana palava liekki,joka rohkaisee jaksamaan ja kurkottamaan eteenpäin. Samalla toivo on herkkää ja kaunista kuin teoksen kannen kukkivat kultaiset köynnökset.

Toivo, sen yksilöllinen ja yhteiskunnallinen voima, on saanut viimeisten vuosikymmenten aikana kasvavaa huomiota yhteiskuntatieteissä. Globaalien ja nopeiden muutosten värittämää aikaamme on jopa kutsuttu toivon ajaksi: turvattomuuden ja epävarmuuden keskellä on kuitenkin aina sijaa toivolle. 
Käsite pilkahtelee niin kansainvälisissä maahanmuuttoa, terrorismin vastaista sotaa, ilmastonmuutosta kuin esimerkiksi alkuperäiskansojen oikeuksia koskevissa tutkimuksissa. (Ks. Lindroth \& Sinevaara-Niskanen 2019; 2021.) Tähän keskusteluun Saarisen teos on erinomaisen tervetullut lisä erityisesti koska, kuten kirjoittaja itsekin toteaa, toivon tematiikasta on kirjoitettu kotimaisesti vähän. Oppi toivosta päättää Saarisen laajemman kolmeosaisen sarjan (Oppi rakkaudesta 2015, Oppi luottamuksesta 2017), mutta on luettavissa täysin itsenäisenä teoksena.

Kirja on jaettu yhdeksään lukuun, joissa avataan niin toivoa koskevan keskustelun aatehistoriallista ja filosofista taustaa kuin sen mahdollisuuksia auttaa jäsentämään päivänpolttavia ympäristöön tai esimerkiksi tiedepolitiikkaan liittyviä kysymyksiä. Teen jäljempänä joitakin lukuihin liittyviä nostoja. Vaikka Saarinen kuvaa omaa toivoon liittyvää intressiään monitieteiseksi, on teoksessa selkeä uskonnontutkimuksellinen ja teologinen painotus. Tunnustan rehellisesti, että pohdin teoksen alkupuolella, mikä on kirjan anti kaltaiselleni toivon valtaa pohtivalle kriittiselle politiikkatieteilijälle. Samaan aikaan hieman pelkäsin, Saarisen viitatessa Lutherin, Paavalin ja Tuomas Akvinolaisen ajatuksiin, olevani liian tuntemattomilla teologisilla vesillä. Huoli osoittautui ennenaikaiseksi ja pelko aiheettomaksi. Koin teoksen laajaalaisen humanistisen keskustelun sivistävänä ja omaa ajattelua inspiroivana. Saarisen teologiaan nivoutuva tapa kuljettaa keskustelua antiikin filosofiasta nykypäivään herätti minut pohtimaan muun muassa, kuinka pitkä yhteinen historia politiikalla ja uskonnolla on ja kuinka se kenties kaikuu nykypäivän politiikan puheessa toivosta.

Teoksen argumenttina on ajatus toivosta avoimuutena, ja tämä näkökulma myös sitoo kirjan Saarisen aikaisempiin pohdintoihin rakkaudesta ja luottamuksesta. Kuten Saarinen kirjoittaa, avoimuus merkitsee "toiminnan kohteena olemista ja minän ulottumista mahdollisiin maailmoihin kuvittelukyvyn avulla" (s. 18) Hän jatkaa, että "toivo voidaan ymmärtää avoimuudeksi, jolla suuntaudumme tulevaisuuteen" (s. 179), mutta vaikka toivomiseen "kuuluu sitä kohti kulkeminen", avoimuutena toivo voi olla muutakin, jotakin yllättävää,kuin "jo oletetun kohteen tavoittelua” (s. 148). Avoimuuden rinnalla Saarinen kuljettaa kirjan läpi sovellustaan Kantin toivokäsityksestä. Kantin esittämään tiivistelmään järjestä sisältyvät kysymykset: "Mitä voin tietää?", "Mitä minun tulee tehdä?" ja "Mitä saan toivoa?" (s. 50). Saarisen sanoin Kant ei sinällään käsittele toivon luonnetta tai kaikenlaista toivomista, vaan pohtii "järjen lopullista päämäärä, korkeimman hyvän ideaalia" (s. 51). Saarinen johtaa Kantin ajatuksista myös päätelmän toivosta: "hyvää pitää tehdä, onni pitää ansaita, ja lisäksi näihin asioihin kuuluu toivo päästä osalliseksi hyvän vaikutuksista" (s. 52).

Kantilainen toivokäsitys voi äkkiseltään tuntua vaikealta paikantaa. Saarinen tarjoaa kuitenkin mielestäni hyvin onnistuneet sovellukset näkökulmastaan teoksen ympäristökysymyksiä ja yliopistopolitiikkaa koskevissa luvuissa Luvussa viisi, Ympäristökriisi ja toivo, hän pohtii humanistisen tutkimuksen roolia ilmastonmuutoksesta käytävässä keskustelussa. Saarinen esittää kantilaista ajattelua lähestymistapana, joka voisi tuottaa 
jotakin uutta. Kuten hän toteaa, ilmastonmuutosta koskeva keskustelu on puhetta tulevasta ja tulevaisuuteen puolestaan limittyy olennaisesti toivo: "[m] e kaikki toivomme jotakin ja pelkäämme jotakin ilmastonmuutoksen edessä. Niin poliittinen kuin yksilöiden välinen keskustelu on sakeana toivon ja huolen näköaloista.” (s. 90). Tähän toivon täyttämään aikaan kantilainen toivokäsitys lisää vaatimukset tietämisestä ja tekemisestä. Ilmastonmuutoksenkin edessä, Saarisen ajatusta seuraten, oikeus toivoa syntyy vain, kun ottaa selvää asioista ja pyrkii tekemään parhaansa. Yksilölliset, ja laajemmin yhteiskunnallisetkin, toiveet ympäristön tilasta ovat oikeutettuja, kun on ensin selvitetty faktapohja ja toimittu sen ohjaamana. Kääntäen, jollei ole tietoja ja tekoja, ei ole oikeutta esittää toiveita. Saarinen kuitenkin muistuttaa, ettei esimerkiksi henkilökohtainen muutos ole kantilaisessa mielessä "terapointia eikä varsinkaan ulkokultaisuutta" vaan "oikeutetun toivon käsitteellinen edellytys, sen mahdollinen ehto" (s. 91). Näen, että ajatusta voisi jatkaa muun muassa kansainvälisten ympäristösopimusten ja -neuvotteluiden tarkasteluun: mitä tiedetään ja on tehty ennen kuin on määritelty toiveita tulevasta?

Teoksen päättävässä luvussa yhdeksän, Toivo yliopistossa ja koko maailmassa, Saarinen nivoo kantilaisen toivokäsityksensä osaksi ajankohtaista yliopistopoliittista keskustelua. Pohdinnassa sivistys- ja saavutusyliopistojen taustoista, eroista ja niille asetetuista toiveista korostuu juuri kysymys toivon oikeutuksesta. Strategioiden monenmoiset toiveet, joilla pyritään ohjaamaan, kenties rajaamaankin, sivistysyliopistojen toimialaa näyttäytyvät kantilaisen ajattelun valossa absur- deina. Kuten Saarinen toteaa, tieteen autonomiassa ei ole lopulta kyse "vallanjaosta vaan siitä, kenellä on oikeus toivoa" (s.173). Kantaessaan huolta sivistysyliopiston tulevaisuudesta, vapaudesta ja itsehallinnosta Saarinen huomauttaa osuvasti, että juuri tiedon ja toiminnan kautta "yliopistoyhteisö pystyy yhdessä esittämään sellaisia oikeutettuja toiveita, joita ulkopuolelta on vaikea esittää" (s. 173). Pidin lukua kritiikissään oivallisena ja erinomaisena esimerkkinä siitä, miten moniin asioihin toivo nykypäivänä kietoutuu. Saarisen pohdintaa toivon ja yliopistopolitiikan oikeutuksesta voisi hyvin jatkaa kysymyksillä toivon vallasta.

Kokonaisuudessaan Saarisen teos on samalla sekä hyvä perusteos toivosta että inspiraation lähde erilaisille käsitteellisille tulokulmille ja sovelluksille. Näen, että teos tai sen yksittäiset luvut, hyvin pohjustettuina, soveltuvat myös moninaisesti opetuskäyttöön. Erityisesti suosittelen teosta kaikille tutkijakollegoille, joiden teemoihin keskustelu toivosta nivoutuu. Fyysisen kauneutensa ja kielellisen sujuvuutensa lisäksi kirja tarjoaa ajattelullisen lahjan, johon kannattaa tarttua.

\section{KirjallisuUs}

Lindroth,Marjo \& Sinevaara-Niskanen,Heidi (2021) Politics of Hope:Transformation or Stagnation? Teoksessa S.A. Hamed Hosseini, James Goodman, Sara C. Motta \& Barry K. Gills (toim.) The Routledge Handbook of Transformative Global Studies. Abingdon: Routledge, 230-242. https://doi. org/10.4324/9780429470325-17

Lindroth, Marjo \& Sinevaara-Niskanen, Heidi (toim.) (2019) Politics of Hope teemaosio. Globalizations 16 (5), 644-706. https://doi.org/10.1080/14747731.2018. 1560694 